\title{
MAGYARORSZÁGI GAZDASÁGI KÖZPONTOK ÉS MOBILITÁSI HAJLANDÓSÁG A TELEPHELYI TÉNYEZŐK TÜKRÉBEN
}

\author{
KOLTAI ZOLTÁN \\ HUNGARIAN ECONOMIC CENTRES AND THE WILLINGNESS OF \\ MOBILITY IN THE LIGHT OF BUSINESS LOCATION
}

\begin{abstract}
We developed a layered questionnaire survey in 2004-2005 and received replies from one thousand entrepreneurs and business leaders to our questions relating to the successfulness of Hungarian towns and cities. In the light of the results, we repeated our survey in 2016-2017, thereby allowing a comprehensive evaluation of a period of ten years. In the second phase of data recording we used the method of a layered questionnaire survey again (the three aspects considered were as follows: a breakdown of the Hungarian businesses by regions, company size, and sectors), in which one thousand entrepreneurs and business managers again responded to our questions. What aspects do Hungarian businesses prefer when choosing their business location? Which Hungarian cities are considered competitive by company leaders and why? Which are the cities that the stakeholders see as real economic centres? What willingness of mobility within Hungary and abroad is typical for the Hungarian businesses?
\end{abstract}

Keywords: successfulness, aspects of business location, mobility, economic centre

\section{Bevezetés}

A magyar települések telephelyi sikerességét mára elsősorban belső adottságaik határozzák meg. A településhierarchiában elfoglalt pozíció, a közigazgatási szerepkör mellett (de nem helyett) meghatározó faktorrá az egyes települések gazdasági adottságai, jövedelemszerzési lehetőségei váltak (BELuSzKY P. 2000; LENGYEL I.-RECHNITZER J. 2000; Egedy T. 2012; Csomós Gy. 2013; Tóth G.-NAGy Z. 2013; Harcsa I. 2015). A közszolgáltatásokkal szemben megerősödött a piaci alapú tevékenységek, főként a modern üzleti szolgáltatások magyarázó ereje, ami a tercier vállalkozások rugalmasabb telephelyválasztásán keresztül még több falu és város számára tette lehetôvé a gazdasági folyamatokba történő aktív bekapcsolódást. Az előzőekkel szoros összefüggésben felértékelődött a települések földrajzi elhelyezkedése, megközelíthetôségük (BAKOS N. et al. 2011), infrastrukturális ellátottságuk (EHRLICH É. et al. 2006), történelmi-kulturális adottságaik (BARANYAi N.-BARÁTH G. 2009; FÁBiáN A.-Tóth B. I. 2013; FAZEKAS N.-FÁBiÁN A. 2015), humán erőforrásaik képzettsége, az innovációt hordozó intézmények jelenléte (RECHNITZER J. et al. 2004; Lengyel I. 2012; KonCZOSné SzOMBATHELYi M. 2014), környezeti állapotuk (MAKRA L.-SÜMEGHY Z. 2010) és nem utolsósorban a helyi fejlesztéspolitika aktivitása. Azt is mondhatnánk, hogy a rendszerváltozással párosuló lehetőségeket azokban a térségekben tudták a legjobban kihasználni, ahol a képzett népesség gazdasági előnynyé tudta alakítani felhalmozott szellemi-kulturális és kapcsolati-információs tőkéjét. Amennyiben ezek a tényezők egy térségben viszonylag kedvező infrastrukturális adottságokkal párosultak, szinte biztos volt a kedvező folyamatok beindulása. A verseny regionális dimenziója felerősödött és a régiók közötti differenciák váltak elsődlegessé, míg az adott régión belüli településszintek között jelentősen mérséklődtek a különbségek. Mindez egyértelmúen a regionális hovatartozás versenyképességet befolyásoló szerepének megerősödését jelzi. 
Mivel a gazdaság telephelyválasztása piacgazdasági törvényeket követ, egyértelmúen láthatóvá váltak azok a települési differenciák, melyeket az állami tulajdonú gazdaság korábbi, nem piaci jellegú döntései még elfedtek (ENYEDI Gy. 1993; NEMES NAGY J. 1996). A tercierizálódás, kiemelten az üzleti és pénzügyi szolgáltatások dinamikája főváros-vidék relációban hozott létre térségi differenciálódást, az ipar megváltozott térszerkezetben történt újjászervezése viszont a nyugati és keleti országrész dualizmusát eredményezte. Mindkét folyamat mögött a külföldi tőke meglehetősen egyenlőtlen térségi megjelenése állt (NAGY G. 1995; BARTA Gy. 2000). A siker és a településhierarchiában elfoglalt pozíció között igen szoros kapcsolat mutatkozik. A nyertesek azok a közép- és nagyvárosok lettek, melyek nem csak nagyobb népességgel és vonzáskörzettel, de többszintú, részben piacgazdasági intézményrendszerrel és magasabb jövedelemtermelő képességgel is rendelkeznek. Térségi hatásuk új, alapvetően fogyasztásra épülő dimenzióval szélesedett az elmúlt évtizedekben. Amellett, hogy eleve kedvezőbb induló feltételek párosultak hozzájuk, hiszen a közmúvek nagy része, a nagyobb vállalatok központjai többnyire náluk összpontosultak, fejlett általános és humán infrastruktúrájuk okán is főként rájuk koncentrált a külföldi múködőtőke. A versenyképesség erős hierarchikus meghatározottsága okán kijelenthető, hogy közép- és nagyvárosaink vonzása részben ellensúlyozhatja kedvezőtlen földrajzi fekvésüket is. Bár a kis- és közepes méretú városok sem humán-, sem intézményi adottságaikat tekintve nem rendelkeznek nagyvárosi feltételekkel, a tartós gazdasági növekedést mutató régiókban egy hálózat részeként fejlesztőleg hathatnak környezetükre (HARCSA I. 2015). A különféle aspektusú kutatások eredményei alátámasztják a fejlettséget megosztó fóbb dimenziók, így a főváros-vidék, a nyugat-kelet és a város-vidék jellemzők tovább élését.

Az elmúlt évtizedek funkcionális és regionális értelemben lezajlott homogenizálódási folyamatai okán városaink egyértelmú ágazati vagy funkcionális besorolása aktuálisan nem lehetséges (BEluszKy P. 2003; Pirisi G.-TrócsánYi A.-HAJNAL K. 2018). Bár a megfigyelhető uniformizálódás következményeként kevés a sajátos karakterû, kimondottan jellegadó funkcióval leírható város, egyaránt érdekes összehasonlításra adnak alkalmat a városaink komplexitását (városhierarchia, várostörténeti jellegzetességek, funkcionális jellemzők, dinamizmus) vagy innovációs környezetét alapul vevő típusképzési törekvések. Előbbi esetben (BELUSZKY P. 2003) altípusokkal együtt mintegy 20 csoportban, utóbbi kutatás során (REChNitzer J.-CSizMAdia Z.-Grosz A. 2004; NÁRAi M. 2005) 11 klaszterben szerepel a hazai városhálózat.

\section{Elméleti háttér - Telephelyválasztási döntések}

A területi értelemben vett sikeresség elméleti hátterének fontos részterületét jelentik a telephelyelméletek, melyek a társadalmi és gazdasági tevékenységek térbeli elhelyezkedését befolyásoló legfontosabb tényezőket kutatják, legyen szó akár profitorientált gazdasági szervezetekről, közszolgáltatást nyújtó intézményekről vagy háztartásokról. (A megválaszolandó alapkérdés egy mondatban: „Miért ott folyik egy gazdasági tevékenység és nem máshol?’'LENGYEL I.-RECHNITZER J. 2004,p. 90.) A valódi választás lehetősége leginkább az ipari forradalmat követően jelent meg. A szükséges technikai-múszaki háttérfeltételek és infrastruktúra kiépülése, a szállítási eszközök fejlődése, a tőke és munkaerő szabadabb térbeli mozgása ekkortól biztosították a nyersanyagok, termelési tényezők és késztermékek tömeges szállíthatóságát, lehetővé téve az árutermelő gazdaság térbeli kiterjedését, a tömegtermékek előállításának és széleskörü kereskedelmének elterjedését. Ettől kezdve a közgazdaságtan klasszikusnak számító kérdőszavai (mit, hogyan, kinek), kiegészülnek egy újabbal, a hol kérdéssel. A tudatos telephelyválasztás mindig konkrét üzleti kalkulá- 
ciókat feltételez, melyben gazdasági (pénzügyi) és gazdaságon kívüli szempontok egyaránt megjelennek. A hagyományos telephelyelméletek (ide sorolhatjuk JOHANN VON THÜNEN mezőgazdasági területhasználattal kapcsolatos elméletét, ALFRED WEBER ipari telephelyelméletét, AUGUST LöSCH térbeli versennyel és egyensúllyal kapcsolatos vizsgálatait) még alapvetően a mezőgazdaság és a feldolgozóipar térbeli jellemzőit modellezték, központi kategóriaként kezelve a költségek minimalizálását, a gazdasági profit megszerzését (ReChnitzer J. 1994; VARGa A. 2002; LENGyel I.-REChNitZer J. 2004; ENYEDi Gy. 2012). Az első elméletek még racionális és teljeskörûen informált gazdasági döntéshozókat feltételeztek, modelljeik alapvetôen statikusak voltak, így azok csak rövidtávon értelmezhetôk. Napjainkra ezek túlhaladottá váltak, hiszen a szolgáltatások megnövekedett szerepével, az egyedi termékekre irányuló fogyasztói kereslet fokozódásával, a vállalati hálózatok, klaszterek, valamint a gazdaságon kívüli, kevésbé vagy egyáltalán nem számszerúsíthetô szempontok, externáliák térnyerésével már a korábbiaktól lényegesen különböző tényezők is befolyásolják a helyszínválasztást. A nem vagy nem teljeskörúen megmagyarázott empirikus problémák tisztázásának szándéka idézte elő az új kereskedelmi elméletek megszületését. Ezek az elméletek központi fogalomként használják a külső (iparági) és a belső méretgazdaságosságot, a termékdifferenciálást, a piacszegmentációt, az árdiszkriminációt és a nem tökéletes versenyt. PAUL KRUGMAN véleménye szerint a nemzetközi gazdaság múködésének, specializációjának megértéséhez a nemzeti, azon belül pedig a regionális gazdasági növekedésben mutatkozó különbségek feltárása szükséges (KRUGMAN, P. 1993, 1994, 1998). Szintén a gazdasági tevékenységek térbeli eloszlásával kapcsolatosak ALLEN J. ScotT kutatásai (SCOTT, A. J. ET AL. 2001). Szerinte a tranzakciós (szállítási, kommunikációs) költségek minimalizálása a legfontosabb determináns a telephely-választási döntések során, miközben figyelmet fordít a technológiai externáliákra is. MICHAEL STORPER nem-üzleti kapcsolatokon alapuló modelljében a gazdasági szempontok mellett társadalmi szempontok mentén csoportosítja a regionális fejlődés alaptényezőit. Modelljében a korábbi elméletekhez képest nagyobb szerepet szán a döntéshozók kapcsolatrendszerének, viselkedésének, követett tradícióiknak. A tranzakciós költségekre és az extern hatások erősségére építő Scott-féle modellt Storper továbbfejleszti (STORPER, M. 2000; SCOTT, A. J.-STORPER, M. 2003). A szerző a tranzakciós költségek két típusát különbözteti meg, beszél egyrészt térbeli tranzakciós költségekről, másrészt az együttműködés tranzakciós költségeiről, végül ezeket kombinálja az externáliákkal. RAYMOND VERNON a termékek eltérő technológiai és inputkövetelményeit összekapcsolja azok életciklusával (VERNON, R. - WELLS, L.T. 1991). Termékciklus koncepciója abból az alapfeltételből indul ki, hogy egyrészt jelentős különbségek mutatkoznak az egyes országok szellemi tókével, $\mathrm{K}+\mathrm{F}$ kapacitásokkal való ellátottságában, másrészt a termékek inputigényei, termelési feltételei, ezen keresztül komparatív előnyei életciklusuk során jelentősen módosulhatnak. Mindennek egyértelmú területi vonatkozásai is léteznek. A vállalati stratégiai közgazdaságtan (kompetitív elónyök elmélete) visszavezethető MicHAEL PORTER munkásságára. Szerinte a globális vállalati verseny forrásai földrajzi koncentrációt mutatnak, a verseny tulajdonképpen a lokális előnyöket biztosítani képes térségek között értelmezhető. A szerző empirikus kutatásaira támaszkodva úgy véli, hogy a térségek, városok versenye alapvetően a helyben múködő (letelepedni szándékozó) vállalatok sikeressé válásához való hozzájárulást jelenti, az ezt elősegítő üzleti környezet megteremtése által. Az egyes országok, régiók kompetitív elōnyét visszavezeti a globális iparágakban múködő, egyben az adott országban hazai bázissal rendelkező vállalatok sikerességére. Ezek alapján fontos megválaszolandó kérdés egy régió életében, hogy az ott múködő vállalatok számára a régió térségi bázisul is szolgál-e, vagy mindössze a másodlagos fontosságú vállalati funkciók helyszíne. Egy régió alulról szerveződő gazdaságfejlesztési stratégiájában elsődlegességet kell élvezzenek azok a helyi 
tényezők, amelyek a régióban múködő versenyképes vállalkozások és iparágak versenyelőnyeihez szükségesek. A szerző épít a pozitív lokális extern hatásokra, melyeket, mint agglomerációs előnyöket a versenyben való sikeres helytállás alapfeltételeként határoz meg (PORTER, M. E. 1996, 1999, 2000). Porter véleménye szerint a tartós vállalati versenyelőnyök egyre inkább nem-áthelyezhetô, térségi bázisban koncentrálódó tényezőktől függenek, melyek pontosan lokalitásuk okán nehezen utánozhatók. Széles körben ismertté vált rombusz (gyémánt) - modelljében azokat a tényezőket gyűjtötte össze (tényező feltételek, keresleti feltételek, támogató és kapcsolódó iparágak, vállalati stratégia és versengés összefüggései), melyekre egy adott földrajzi térben a globális vállalatok, iparágak versenyelőnye visszavezethető (PORTER, M. E. 1990, 1999, 2000). Arra a kérdésre keresett választ, hogy milyen meggondolások alapján választ egy cég telephelyet, és a választás eredményeként milyen kompetitív előnyökre számíthat. Végül újabb keletú magyarázatként érintenünk kell a területitőke-elméletet. Területi tőke alatt a helyi eróforrások együttesét, eróforrás-portfólióját értjük, benne anyagi (megfogható) és nem anyagi (nem megfogható) tényezőkkel, melyek nagysága, összetétele és főleg hasznosíthatósága régiónként jelentősen különbözik. ROBERTO CAMAGNI meglévő belső eróforrásokra, endogén tényezőkre építő elméletében a tőkejavak tulajdonosi szerkezetét a javak tárgyiasultsági fokával kombinálja (CAMAGNI, R. 2008, 2009). Modelljének négy sarokpontját a természeti és kulturális erőforrások, a magántőke, a humántóke és a társadalmi tőke alkotja, melyek között különféle intézmények, szolgáltatások, formális és informális együttmúködések (hálózatok, cselekvések, kompetenciák) biztosítják a múködési kapcsolatot. A szerző szerint a területi tőke adott helyre, adott időpontban jellemző állapotot mutat meg, az egymásra hatások eredményeként egyúttal folyamatosan változik. A megközelítés a humán, a kapcsolati és a társadalmi tôke szerepének hangsúlyozásával még inkább kiemeli a helyi szereplők aktív részvételének jelentőségét az endogén térségfejlesztési folyamatokban.

Amennyiben megpróbáljuk összegyújteni a telephelyválasztásban megjelenő befolyásoló tényezőket, egy meglehetősen terjedelmes listát kapunk. Ide sorolhatók többek között a szállítási és egyéb infrastrukturális lehetőségek, a természeti környezet adottságai, a piacok (fogyasztói kereslet), a legfontosabb inputok, a társadalmi-kulturális környezet, az externáliák és a központi, helyi kormányzati politika egyaránt. Vagyis a szempontok között találunk olyanokat, amelyek az inputok beszerzéséhez, olyanokat, melyek az outputok piacra juttatásához kapcsolódnak, s végül megjelennek közöttük extern hatások is. Mindez alátámasztja, hogy a telephelyválasztások meglehetősen komplex döntési problémák,és mindig különböző tényezők kombinációin alapulnak (KISS É. 2010; JózSA V. 2017).

De vajon mit gondolnak erről a leginkább érintett szereplők, maguk a vállalkozások? Hogyan látják ők saját környezetük legfőbb előnyeit és hátrányait? Ezekre a kérdésekre próbáltunk választ találni magyarországi kérdőíves vizsgálatunkkal.

\section{A kutatás módszertani háttere}

A rendszerváltozástól napjainkig élénk érdeklődés mutatkozik a magyar településhálózatban elfoglalt pozíciók értelmezése iránt. Elsősorban azzal a szándékkal történik mindez, hogy a kutatók feltárják, melyek voltak az átrendeződés legfőbb mozgatórugói. A vizsgálatok egy része komplex módon kezeli a telephelyválasztás kérdéskörét, annak elemzésekor a szerzők a befolyásoló tényezők szélesebb körére fordítanak egyidejűleg figyelmet. Más megközelítések egy-egy aspektusra, részterületre koncentrálnak (munkaerőpiaci, humán erôforrás adottságok, innováció, infrastrukturális ellátottság, települési funkciók száma és választéka, környezeti minőség, nemzetközi beágyazottság) így formálva véleményt 
a települések vonzerejéről. A nagyszámú, döntően statisztikai adatbázisokra építő hazai kutatás kérdése igazán nem a térbeli egyenlőtlenségek létével kapcsolatos, hanem sokkal inkább az, hogy a létező területi különbségek mértékét mekkorának ítélik a szakemberek, és azok változási irányát hogyan érzékelik. Az esetleges nézetkülönbségek mögött ugyanúgy megtaláljuk a területi egyenlőtlenségek többdimenziós jellegét, a számszerúsítés többfajta lehetőségét, ahogy a kapott eredmények értelmezésében megmutatkozó eltérő szemléletmódokat is. Véleményünk szerint a statisztikai adatok elemzését jól kiegészíti a mögöttes, társadalmi-gazdasági folyamatokat is bemutató, kérdőíves adatfelvételen alapuló vizsgálatunk.

Vállalatokkal kapcsolatos 2004-2005-ben lefolytatott kutatásunkat 2016-2017-ben ismételtük meg (KolTAI Z. 2007, 2014). A rétegzett kérdőíves megkeresések (magyarországi vállalkozások régiók, vállalati méret és szektorok szerinti megoszlása) eredményeként ismételten ezer vállalkozó, vállalatvezető adott választ kérdéseinkre $(n=1000)$. A vállalkozások aktuális megoszlását alapul véve, $40 \%$ feletti arányban a közép-magyarországi régióból kerültek ki a válaszadók, a többi régiót 8-12\% közötti arányban képviselték a megkérdezettek. Kvantitatív vizsgálatunk során valamennyi magyarországi megyéből szerepelnek válaszok. Vállalati méret szerint a mikro- és kisvállalatok $96 \%$ feletti arányban szerepelnek mintánkban, szektorok szerint a tercier ágazat képviselői közel 80\%-os, az agrárvállalkozások 3,5\%-os előfordulással képezték le a vállalati populációt. A személyes lekérdezéseknek köszönhetően a kitöltött kérdőívek szinte kivétel nélkül alkalmasak voltak a kiértékelésre. Kérdőívünkben három zárt, három nyitott és egy félig zárt, összesen hét kérdés keretében az alábbi témakörökre kerestünk választ:

- Milyen szempontokat részesítenek előnyben a magyar vállalati szféra szereplői telephelyük megválasztásakor?

- Melyik magyarországi településeket, és miért tartják versenyképesnek a vállalatvezetők?

- Melyek azok a települések, melyeket valódi gazdasági központoknak tartanak az érintettek?

- Milyen belföldi és nemzetközi mobilitási hajlandóság jellemzi a magyar vállalkozásokat?

Elemzéseink során kétféle szempontot követtünk: 1. a mutatószámok abszolút értékeinek időbeni változása a megelőző kutatás 2004-2005-ös bázisadataihoz viszonyítva, 2. relatív térbeni összehasonlítások elvégzése a második, 2016-2017-es adatfelvétel időpontjára értelmezve.

\section{Kutatási eredmények}

\section{A telephelyi tényezók értékelése}

Az első kérdés keretében arra kerestünk választ, hogy az általunk kiválasztott telephelyi tényezők mennyire fontosak a múködési helyszín kijelölésekor. Az alábbi tizenkét szempont értékelésére kértük a válaszadókat egy ötfokozatú skálán:

1. a település gazdasági szerkezete (ágazati szerkezet, kapcsolódó iparágak, beszállítói kapcsolatok, háttéripar fejlettsége)

2. a település innovációs kultúrája, szellemi tőkepotenciálja (kutatás-fejlesztési kapacitások, felsőfokú oktatási intézmények, kutatóintézetek léte)

3. a regionális elérhetőség, a település földrajzi fekvése (közlekedési infrastruktúra, Budapest megközelíthetősége) 
4. a múködéssel kapcsolatos költségek (munkabérek, adók, adókedvezmények)

5. a helyi önkormányzat aktivitása, településpolitikája (befektetés ösztönzés, városmarketing, ügyintézés menete, konfliktuskezelés módja)

6. a település környezeti minősége (lakóhelyi adottságok, természeti és épített környezet, szabadidős, egészségügyi és oktatási intézmények)

7. a település közintézményekkel való ellátottsága (közszolgáltatások, hivatalok múködése)

8. a település üzleti szolgáltatásai (bankhálózat, ipari parkok, vállalkozásfejlesztési iroda múködése)

9. a munkaerő felkészültsége és hatékonysága (iskolai végzettség, nyelvismeret, munkatermelékenység, munkaerő-piaci adatok)

10. a település, mint felvevőpiac (piacméret, fogyasztói potenciál, vonzáskörzet jelleg)

11. a település demográfiai és társadalmi adottságai (korszerkezet, migrációs folyamatok, népsűrűség)

12. a település nemzetközi kapcsolatrendszere (külföldi érdekeltségú vállalkozások és beruházások, testvérvárosi kapcsolatok, turizmus)

Megelőző kutatásunk szempontrendszerét két új tényezővel (demográfiai és társadalmi adottságok, a település nemzetközi kapcsolatrendszere) egészítettük ki, ezzel is tovább árnyalva a válaszadás lehetőségét.

2004-2005-ös kutatásunk válaszadói első helyre a település regionális elérhetôségét, földrajzi fekvését $(3,91)$ sorolták, amit valamivel elmaradva a felvevópiaci jelleg $(3,61)$ követett (KolTAI Z. 2007, 2014). A következő, közepesre értékelt tényezőcsoportot az üzleti szolgáltatások, a település gazdasági szerkezete, a múködési költségek, a munkaerő képzettsége és a közintézményi ellátottság alkották. Sorrendben a környezeti minőség és a helyi önkormányzat településpolitikája következett, a legalacsonyabb értéket a település innovációs kultúrája kapta $(2,42)$.

Első hipotézisként a korábban magasra értékelt tényezők (regionális elérhetőség, felvevőpiaci jelleg) további elsődlegességét vártuk, míg az újonnan bevezetett szempontok közül a települések nemzetközi kapcsolatrendszerének fontosságát feltételeztük, utóbbit fóként a közép- és nagyvállalatok körében.

Újabb kutatásunk eredményei alapján a rangsor első helyére már a múködéssel kapcsolatos költségek kerültek, amit a település regionális elérhetősége és a felvevőpiaci jelleg követ (1.ábra). A következő csoportot a munkaerő felkészültsége és hatékonysága vezeti, megelőzve a település gazdasági szerkezetét, az üzleti szolgáltatásokat, a helyi önkormányzat településpolitikáját, a környezeti minőséget és a közintézményi ellátottságot. Továbbra is a legalacsonyabbra értékelt tényezők körében szerepel az innovációs kultúra, ahogy szintén a lista végén találjuk mindkét új szempontunkat, a demográfiai-társadalmi adottságokat és a település nemzetközi kapcsolatrendszerét. A tényezők többsége egyáltalán nem mutat szektorspecifikus jegyeket. A felvevőpiaci adottságoknál kimutatható bizonyos felértékelődés a tercier szektorban, ezzel szemben a települések üzleti szolgáltatásainak jelentőségét az agráriumban tevékenykedők valamelyest leértékelik.

Kijelenthető, hogy a magyar vállalkozások egyrészt költségérzékenyebbé váltak az elmúlt bő tíz évben, másrészt egyértelmúen felértékelődött számukra a felkészült és hatékony munkaerő megléte vagy éppen annak hiánya. Ezekhez a változásokhoz párosul a helyi önkormányzatok településpolitikai aktivitásának mintegy 30 százalékkal megnövekedett jelentősége, ami a mikroszinttől a nagyvállalati szintig egyaránt megfigyelhető. Első hipotézisünk teljesülése csak részlegesnek mondható, mivel a múködéssel kapcsolatos költségek nem várt módon kerültek a rangsor élére, másrészt a települések nemzetközi kapcsolatrendszerére adott pontérték elmarad előzetes várakozásainktól. 


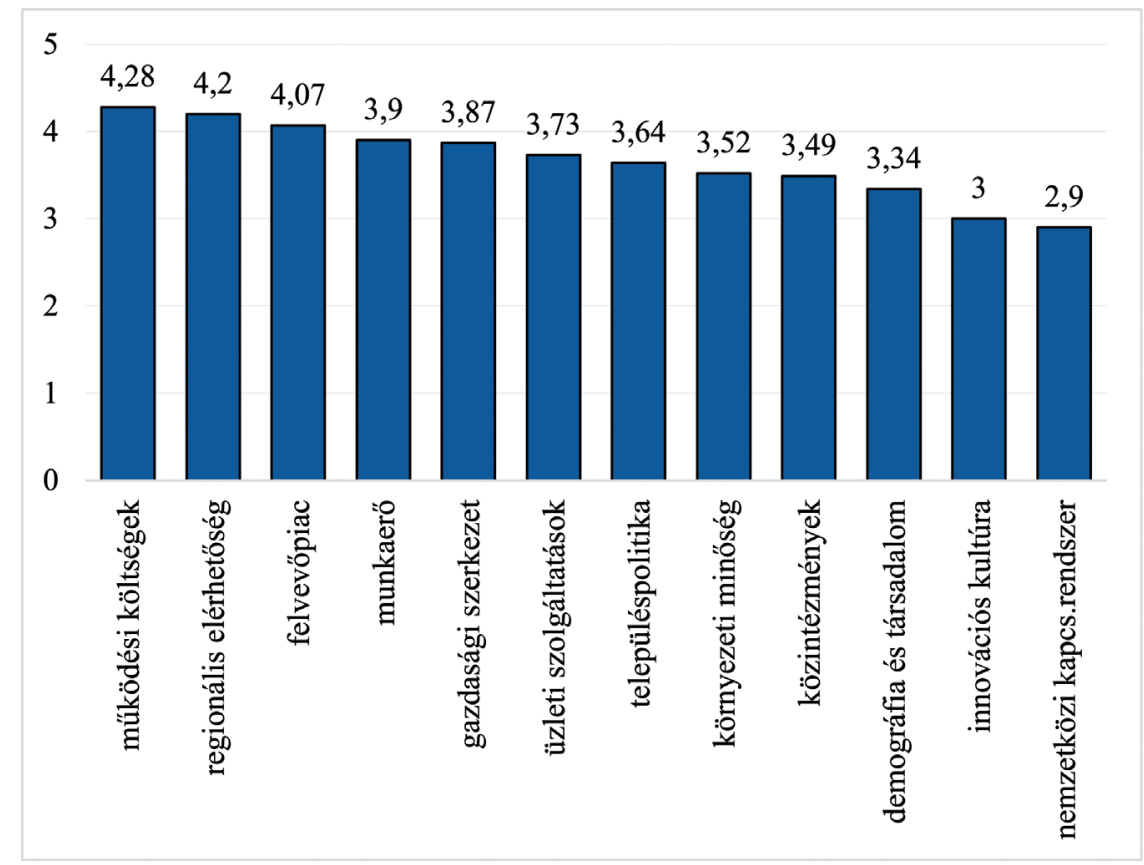

1. ábra A telephelyi tényezők fontossági sorrendje a magyar vállalatok megkérdezése alapján, 2016-2017 Forrás: saját kérdőíves felmérés

Figure 1 Importance of factors of business location, based on the responses of Hungarian businesses surveyed, 2016-2017 Source: questionnaire survey of the author

\section{A települések telephelyi vonzerejének megitélése}

A következő kérdéssel arra kerestünk választ, hogy a magyar vállalatok mely településeket tartják a leginkább versenyképes telephelynek. Mivel Budapest gazdasági értelemben (is) külön kategóriát képvisel a hazai városhálózatban, ezért a fôvárost nem szerepeltettük a kutatás ezen részében.

2004-2005-ös kutatásunk vidéki településekre értelmezett versenyképességi rangsorát Győr vezette (616 említéssel) Székesfehérvár és Sopron előtt, melyeket további megyeszékhelyek, Debrecen, Pécs és Szeged követtek. Tíz évvel ezelőtt összesen 13 olyan települést jelöltek meg a válaszadók, melyek legalább 5\%-os említési gyakoriságot képviseltek. (Az említetteken kívül Szombathely, Kecskemét, Miskolc, Nyíregyháza, Veszprém, Zalaegerszeg és Kaposvár tartozott ide.)

Második hipotézisként továbbra is nagyvárosokat, elsősorban Győrt, Székesfehérvárt, Sopront vártuk az élmezőnybe, valamint Kecskemét jelentősebb felértékelődését is prognosztizáltuk.

Kapott adataink szerint a korábbinál is jobban kiemelkedik a vidéki települések sorából Győr, melyet jelenleg már Debrecen és Székesfehérvár követ (1.táblázat). Szeged alig lemaradva került a negyedik helyre, megelőzve Kecskemétet, Pécset és Sopront. Míg utóbbi két város és Székesfehérvár valamelyest rontott korábbi pozíciójához képest, addig mindhárom alföldi várost aktuálisan kedvezőbben értékelték a megkérdezett vállalkozások. Jelentősebb lemaradással Szombathely következik, majd Nyíregyháza, Miskolc, Veszprém és Budaörs szerepel minimális differenciákkal. Utóbbi város az egyetlen új szereplője az 5\%-os emlí- 
tési gyakoriságot meghaladó települési körnek. (Mindezt jól alátámasztja Budaörs helyi foglalkoztatási szerepkörének elmúlt évekbeli kedvezó irányú változása. PÉNZES J. et al. 2014; Kiss J. P.-SzalKai G. 2014) Zalaegerszeg és Kaposvár ellenben lekerült a jelenlegi listáról. (Kaposvár értékei az országos és a dél-dunántúli rangsorban egyaránt jelentôs pozícióvesztést mutatnak a tíz évvel korábbi válaszokhoz mérten. A régió térszerkezetét és strukturális sajátosságait részletesen elemzi Máté É. 2017.)

1. táblázat - Table 1

Magyarországi települések, mint telephelyek sorrendje a magyar vállalatok megkérdezése alapján, 2016-2017

Ranking of Hungarian settlements as business locations, based on the responses of

Hungarian businesses surveyed, 2016-2017

\begin{tabular}{clcc}
\hline Ssz. & Település & Említések száma & Súlyozott említés \\
\hline 1. & Győrr & 707 & 2930 \\
2. & Debrecen & 382 & 1197 \\
3. & Székesfehérvár & 360 & 1220 \\
4. & Szeged & 344 & 1080 \\
5. & Kecskemét & 324 & 1068 \\
6. & Pécs & 269 & 834 \\
7. & Sopron & 235 & 808 \\
8. & Szombathely & 108 & 318 \\
9. & Nyíregyháza & 81 & 232 \\
10. & Miskolc & 81 & 221 \\
11. & Veszprém & 66 & 183 \\
12. & Budaörs & 64 & 209 \\
\hline
\end{tabular}

Forrás: saját kérdőíves felmérés

Source: questionnaire survey of the author

További sorrend a legalább 2\%-os említési határt elért településeknél: Eger, Tatabánya, Siófok, Zalaegerszeg, Dunaújváros, Szolnok, Érd, Hévíz, Kaposvár, Gödöllő, Esztergom. (Árnyaltabb különbségeket tapasztalunk, amennyiben nem csak az említések száma, hanem az említés sorrendje alapján is megvizsgáljuk a legtöbbször megjelölt településeket. Az ötfokozatú listán 1-5 közötti pontszámot rendeltünk a városokhoz aszerint, hogy azok hányadik helyen szerepeltek az egyes válaszokban.)

Ahogy korábbi vizsgálatunk során, úgy most is egyetlen régióban fordult elő, hogy nem Győrt említették a legversenyképesebb településnek. Tíz évvel ezelőtt az Észak-Alföldön került a rangsor élére Debrecen, jelenleg a közép-dunántúli vállalkozások gondolják ugyanezt Székesfehérvárról.

Amennyiben az ágazatok szerinti listákat külön is elemezzük, kijelenthető, hogy az iparvállalati rangsorban még inkább kiemelkedik Győr, jobb pozíciót ér el Kecskemét, Székesfehérvár és Veszprém, valamint felkerül a listára Tatabánya, Zalaegerszeg, Dunaújváros, valamint Érd (2. táblázat). Ezzel szemben valamivel kedvezőtlenebb megítélés alá esik Szeged, Pécs és részben Sopron. Az agrárvállalkozások szerint Székesfehérvár, Debrecen és Kecskemét megítélése még előnyösebb, ekkor Zalaegerszeg és Szolnok is tagja 
a legversenyképesebbek csoportjának. A mezőgazdasági válaszadók ellenben jelentősen rontanak Sopron, kisebb mértékben Pécs megítélésén.

2. táblázat-Table 2

Magyarországi települések, mint telephelyek sorrendje a magyar iparvállalatok megkérdezése alapján, 2016-2017

Ranking of Hungarian settlements as business locations, based on the responses of Hungarian industrial businesses surveyed, 2016-2017

\begin{tabular}{rlc}
\hline Ssz. & Település & Említések száma \\
\hline 1. & Győr & 141 \\
2. & Székesfehérvár & 71 \\
3. & Kecskemét & 69 \\
4. & Debrecen & 61 \\
5. & Szeged & 46 \\
6. & Sopron & 34 \\
7. & Pécs & 33 \\
8. & Szombathely & 24 \\
9. & Veszprém & 19 \\
10. & Nyíregyháza & 14 \\
11. & Tatabánya & 14 \\
12. & Miskolc & 14 \\
13. & Zalaegerszeg & 11 \\
14. & Budaörs & 10 \\
15. & Dunaújváros & 9 \\
16. & Érd & 9 \\
\hline
\end{tabular}

Forrás: saját kérdőíves felmérés

Source: questionnaire survey of the author

Hipotézisünk teljesült, miszerint csakugyan nagyvárosok, főként régió- és megyeközpontok kerültek az országos versenyképességi rangsor élére, és kivétel nélkül megjelennek a regionális listák második felében az érintett megyék közép- és kisvárosai is. Több alföldi nagyváros (elsősorban Debrecen és Szeged) az általunk vártnál jobb pozíciót birtokol. (Érdekes összehasonlításokra nyújt lehetőséget EGEDY T. (2012) magyar nagyvárosok versenyképességére elvégzett kutatása. A szerző eredményei ugyanis kiválóan előre jelzik az általunk tapasztalt változások irányát.)

\section{Központok a vállalati vélemények tükrében}

Kutatásunk következő kérdése arra irányult, hogy a vállalatok mely településeket tartják valódi vonzásközpontoknak ma Magyarországon. Korábbi eredményeink alapján Budapest az ország valamennyi régiójában megjelent központként, ráadásul az ország öt régiójában a fővárost említették legtöbbször, mint centrumot. A kivételt jelentő Dél-Dunántúlon 2004-2005-ben még Pécs számított elsődleges vonzásközpontnak, míg az Észak-Alföldön 
Debrecent jelölték meg ekkor a legtöbben. Harmadik hipotézisünk szerint a vállalatvezetők valamennyi régióban meghatározó központként tekintenek Budapestre, valamint számítottunk Győr és Kecskemét központi szerepkörének felértékelődésére is.

2004-2005-ös kutatásunk során Budapest a közép-magyarországi régióban elsősorban szolgáltatásai miatt számított vonzásközpontnak, másodlagosan beszerzési és értékesítési helyszínként gondolták a fơvárost számottevőnek. A centrumrégió válaszadói korábban Székesfehérvárt is a vonzásközponti jelentőségú városok közé sorolták. Jelenleg Budapest után már Kecskemétet nevesítették a legtöbben. A fơváros most is elsődlegesen széleskörú üzleti szolgáltatásainak köszönheti centrumfunkcióját, amit közintézményi ellátottsága, kedvező közlekedési infrastruktúrája, valamint felvevőpiaci jellege és előnyös gazdasági szerkezete tovább erősít.

A Dél-Alföldön 2004-2005-ben Szeged valamivel gyakrabban szerepelt a központok között, mint Kecskemét, utóbbi viszont már ekkor azon kevés városok egyike volt, mely saját régióján kívül is gazdasági centrumnak minősült. (Kecskemét az Észak-Alföldön, Székesfehérvár Közép-Magyarországon, Győr a Közép-Dunántúlon került a központi jelentôségú városok csoportjába, kiegészítve azt a véleményt, mely szerint Budapest az egyetlen magyar város, melynek vonzása saját régióján is túlmutat. BAKOs N. et al.2011) Aktuálisan továbbra is Budapest az első számú vonzásközpont a Dél-Alföldön, melyet Kecskemét és Szeged követ. Mindkét dél-alföldi város mind üzleti szolgáltatásaik, mind közintézményi ellátottságuk, mind beszerzési és értékesítési szerepkörük miatt központoknak minősülnek.

A Dél-Dunántúl vállalatai szerint az elsődleges központ mára már Budapest, Pécs mellett Kaposvár került még megemlítésre. Pécs és Kaposvár elsősorban széleskörú üzleti szolgáltatásainak, másodsorban felvevőpiacának köszönheti központ jellegét. (Szeged és Pécs esetében joggal hiányolhatjuk a centrumfunkció magyarázatai sorából az innovációs kultúrához, kutatás-fejlesztési kapacitáshoz kapcsolódó szempontot, ami újfent ennek a tényezőnek a kevésbé meghatározó jelentőségét mutatja.)

Az Észak-Alföldön Budapestet Debrecen és Szolnok követi. Debrecent főleg kedvező gazdasági szerkezete, beszállítói kapcsolatrendszere kapcsán nevesítik, míg Szolnok üzleti szolgáltatásai okán került a centrumok sorába. (Debrecennél a megelőzó kérdések során hangsúlyosnak számító tényezők, így az üzleti szolgáltatások, a közintézményi ellátottság vagy a felvevőpiaci jelleg ezúttal ritkábban szerepelnek.)

A soron következő három régióban nem Budapest, hanem az adott régión belüli városok szerepelnek elsődleges vonzásközpontként. A Közép-Dunántúlon Székesfehérvárt több vállalat gondolja központnak, mint Budapestet. Teszik ezt üzleti szolgáltatásai, közlekedési infrastruktúrája, közintézményi ellátottsága, kedvező gazdasági szerkezete okán. Másodsorban a város innovációs kultúrája és felvevőpiaci jellege is a magyarázatok között szerepel.

Észak-Magyarországon Miskolcot jelölték meg a legtöbben, Eger valamivel ritkábban szerepel a válaszokban. Miskolcot elsődlegesen üzleti szolgáltatásai miatt nevesítik a régió vállalatai, másodsorban közintézményeinek, gazdasági szerkezetének és közlekedési infrastruktúrájának köszönheti centrumfunkcióit. Egernél a közintézményi ellátottság szolgál magyarázatul. (Miskolc esetében a regionális válaszokban említett felvevốpiaci jelleg ezúttal kevésbé hangsúlyos.)

Végül a Nyugat-Dunántúlon nem csak Győr, hanem a régió másik két megyeszékhelye, Szombathely és Zalaegerszeg is több említést kapott centrumként, mint Budapest. Elsődlegesen üzleti szolgáltatásaik, közintézményi ellátottságuk, valamint közlekedési infrastruktúrájuk okán. (Győr esetében, hasonlóan Szegedhez és Pécshez, az innovációs kultúra, kutatás-fejlesztési kapacitás magyarázó szerepe ritkábban jelenik meg.) 
Hipotézisünk megerősítést nyert, mivel Budapest vonzásközpont jellege valamenynyi régióban kimutatható, Győr és Kecskemét pedig elsősorban saját régióján belül tudta megerősíteni centrumfunkcióit.

\section{A telephely potenciális megváltoztatásának okai és annak területi jellegzetességei}

A következő kérdés kapcsán arra voltunk kíváncsiak, milyen mobilitási hajlandóság jellemzi a magyar vállalkozásokat. A kérdőívben a két éven belüli, magát a települést is érintő költözési szándékot, a háttérben meghúzódó okokat, valamint kapcsolódva a kutatás korábbi részeihez, a lehetséges új múködési helyszíneket is vizsgálat tárgyává tettük.

Negyedik hipotézisünk szerint a szolgáltató szektor vállalkozásai körében magasabb a mobilitás és azt is feltételeztük, hogy a gazdaságilag kevésbé fejlett régiók válaszadói valamivel mobilabbnak mutatkoznak.

A mintában szereplő vállalatok 9,2\%-a tervezi, hogy a következő két évben módosítja jelenlegi telephelyét. (Érdekes összevetésre adnak alkalmat a magyarországi nagyvárostérségek tíz évvel ezelőtti kutatási eredményei SzIRMAI V. 2009; MOLNÁR B. 2009.) A legkevésbé az agrárvállalkozások mobilak, esetükben 5,7\% tervez költözést. Ugyanezt az iparvállalatok 9,1\%-a, a tercier szektorban múködők 9,4\%-a gondolja így. Az alacsony elemszám ellenére megpróbáltunk regionális jellemvonásokat is kimutatni (2.ábra). Eszerint a DélDunántúlon a legmagasabb $(13,8 \%)$ az önmagukat mobilnak vallók részaránya, őket Közép-Magyarország (10,5\%), Észak-Alföld (9,5\%), Észak-Magyarország (9,2\%), NyugatDunántúl (7\%), Dél-Alföld (6,7\%), végül Közép-Dunántúl értéke (4,9\%) követi.

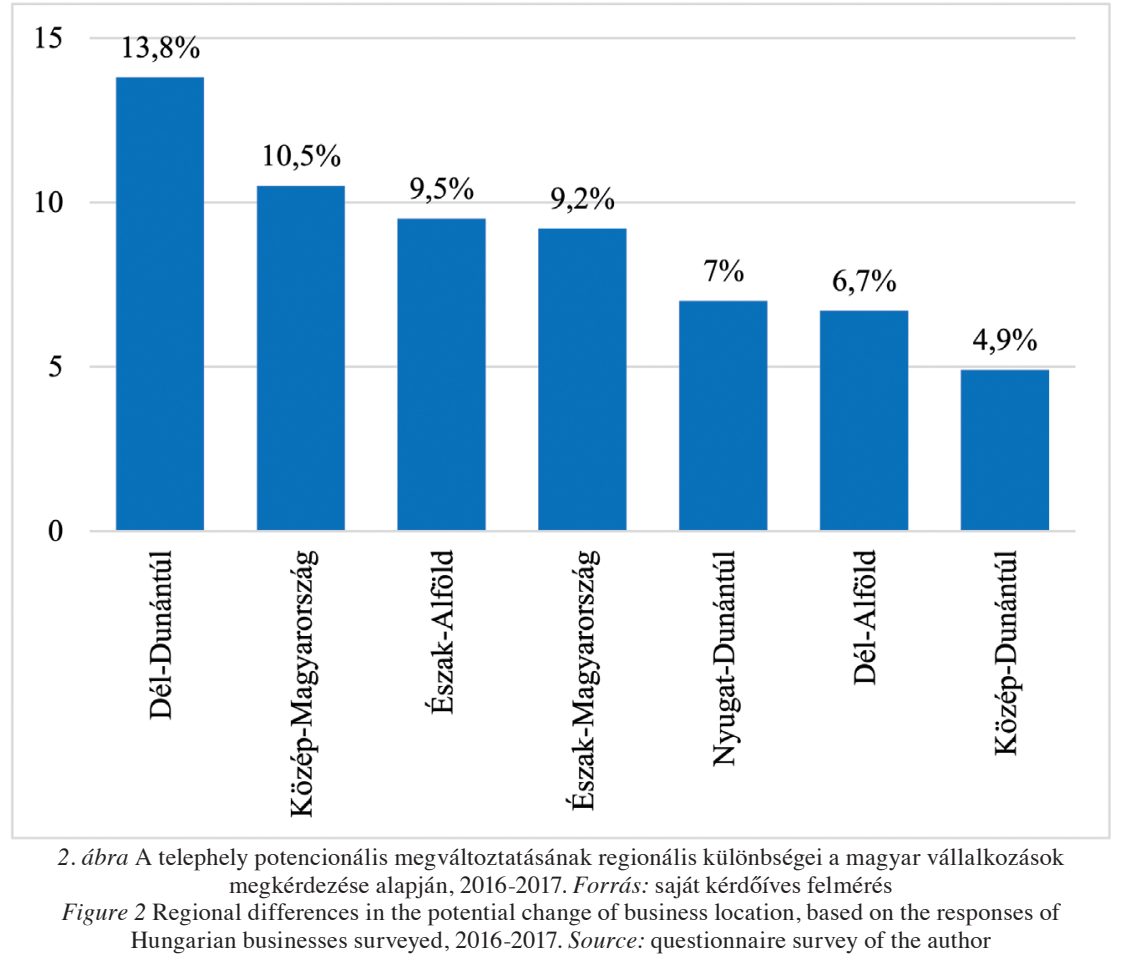


A vártnál magasabb közép-magyarországi értéket részletes elemzés tárgyává tettük (3. ábra). Eszerint a költözési szándékkal rendelkezők egy szúk csoportja (9\%) biztosan a régión belül maradna, harmadrészük (32\%) meg nem nevezett belföldi települést gondol új telephelyének, ami akár régión belül maradást is jelenthet. A mobilnak mutatkozók 23\%-a egyértelmúen Közép-Magyarországon kívüli településeket nevesített, 16\%-uk külföldi telephelyben gondolkodik, 20\%-uk pedig még nem tudja, pontosan hová költözne. Kijelenthető, a költözési hajlandóság szektorális és regionális differenciáival kapcsolatos várakozásunk csak részlegesen igazolódott be.

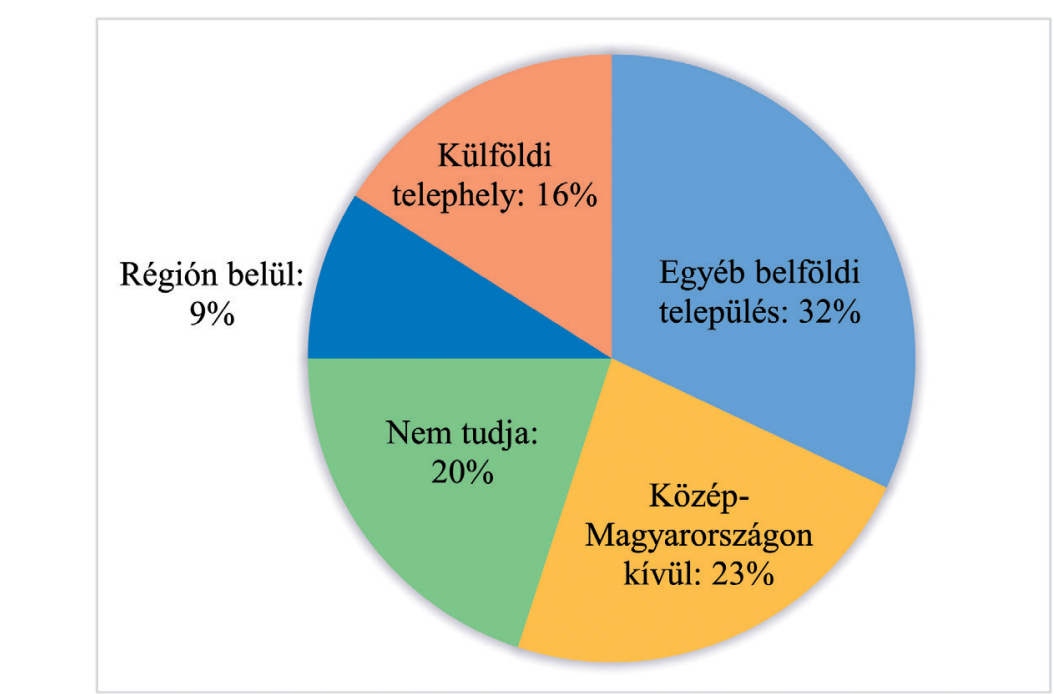

3. ábra A telephely változtatás célterülete a közép-magyarországi vállalkozások megkérdezése alapján, 2016-2017 Forrás: saját kérdőíves felmérés

Figure 3 Target area for the change of business location, based on the responses of Central Hungarian businesses surveyed, 2016-2017. Source: questionnaire survey of the author

Ötödik hipotézisünk szerint a költözési szándékkal rendelkező válaszolók a legfontosabb tényezőket (lásd 1.ábra) említik mögöttes okként, a potenciális új telephelyek pedig a leginkább versenyképesnek gondolt nagyvárosok közül kerülnek ki (lásd 1. táblázat).

A telephely megváltoztatásával összefüggő okokat számba véve (4.ábra) leggyakrabban csakugyan a korábban magasra értékelt tényezők (múködési költségek, regionális elérhetôség, felvevőpiaci jelleg) szerepelnek. Valamelyest felértékelődik a helyi önkormányzat településpolitikájának, befektetés ösztönzésének magyarázó ereje, míg a munkaerő felkészültségének és az elérhető üzleti szolgáltatásoknak kisebb jelentőséget tulajdonítanak a válaszadók. Mindez jól mutatja a települések nagyon eltérő mozgásterét az egyes telephelyi tényezők vonatkozásában, hiszen míg a településpolitika kialakítása autonóm döntésnek számít, addig a munkaerő-piaci adottságok és az üzleti szolgáltatások színvonala már nem kizárólag a helyi döntéshozók belügye. A legalacsonyabbra értékelt tényezők (innovációs kultúra, demográfiai-társadalmi adottságok, a település nemzetközi kapcsolatrendszere) ezúttal is a rangsor végén szerepelnek.

Ami a potenciális új telephelyeket illeti, a leginkább versenyképesnek gondolt nagyvárosok a vártnál kevésbé hangsúlyosan jelennek meg a válaszokban. A mobilnak mutatkozó vállalatok negyede (26\%) nevesítette őket, közülük is a leggyakrabban Győrt. A legtöbben (39\%) „,egyéb belföldi településre” helyeznék át mostani telephelyüket, 25\%-uk 
még nem döntött, míg 10\% azok részaránya, akik külföldre költöztetnék vállalkozásukat. Hipotézisünk teljesülése emiatt csak részlegesnek nevezhető.

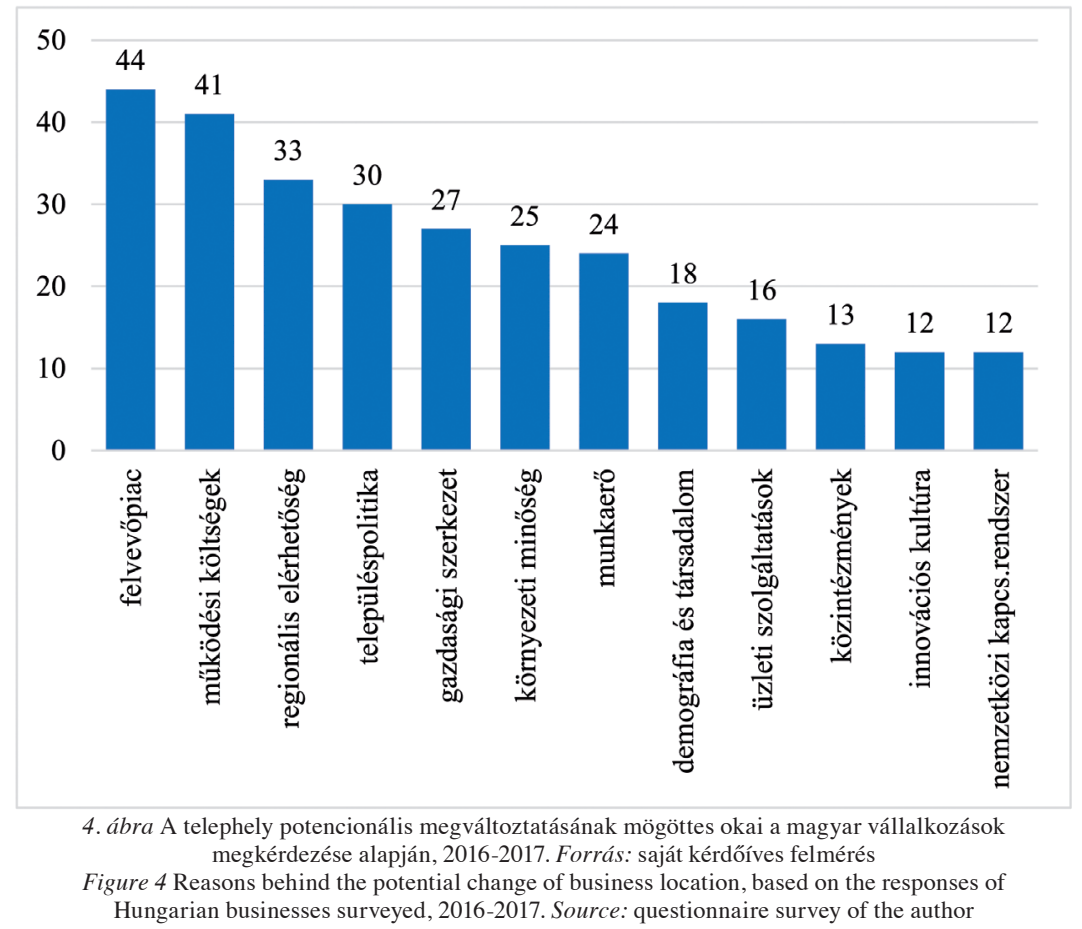

\section{Összefoglalás}

A magyar települések telephelyi sikerességét mára elsősorban belső adottságaik determinálják. Meghatározó tényezővé váltak gazdasági adottságaik, a közszolgáltatásokkal szemben megerősödött a piaci alapú tevékenységek, üzleti szolgáltatások magyarázó ereje. Mindez a tercier vállalkozások rugalmasabb telephelyválasztásán keresztül a korábbinál számosabb, akár kisebb település számára is lehetővé teszi a gazdasági folyamatokba történő aktív bekapcsolódást. A korábbiakhoz képest felértékelődött a települések földrajzi elhelyezkedése, megközelíthetőségük, infrastrukturális ellátottságuk, humán erőforrásaik képzettsége, az innovációt hordozó intézmények jelenléte, környezeti állapotuk, valamint a helyi fejlesztéspolitika aktivitása. A siker és a településhierarchiában elfoglalt pozíció között máig igen szoros kapcsolat mutatkozik. A nyertesek azok a magyarországi léptékben közép- és nagyvárosok lettek, melyek nem csak nagyobb népességgel és vonzáskörzettel, de többszintú, részben piacgazdasági intézményrendszerrel és magasabb jövedelemtermelő képességgel is rendelkeznek, ami részben ellensúlyozhatja akár kedvezőtlen földrajzi fekvésüket is. Bár a kis- és közepes méretû városok sem humán-, sem intézményi adottságaikat tekintve nem rendelkeznek nagyvárosi feltételekkel, a tartós gazdasági növekedést mutató régiókban egy hálózat részeként ezek is fejlesztőleg hathatnak környezetükre.

Kvantitatív vizsgálataink alapján kijelenthetjük, hogy a hagyományos tényezők (múködési költségek, megközelíthetőség, felvevőpiaci adottságok) továbbra is elsődlegesnek szá- 
mítanak a telephelyi döntések során, de az átlagosnál nagyobb mértékben nőtt a korábban periférikusnak számító jellemzők, így a helyi önkormányzatok településpolitikájának, a munkaerő felkészültségének, a település innovációs kultúrájának és környezeti minőségének magyarázó ereje. A nagyvárosok, régió- és megyeközpontok kerültek a telephelyi rangsorok élére, a vállalatok kizárólag ezeket a településeket tartják valódi vonzásközpontoknak. A regionális listák második felében viszont kivétel nélkül megjelennek az érintett megyék közép- és kisvárosai is. A szolgáltató szektor vállalkozásai körében mutatható ki a legmagasabb mobilitási hajlandóság, melynek magyarázataként leggyakrabban a múködési költségek, a regionális elérhetőség, a felvevőpiaci jelleg és a helyi önkormányzat településpolitikája szerepel.

A területi értelemben vett sikeresség mérésének célja elsősorban az, hogy egy adott földrajzi egység helyzetét a lehető legobjektívebb módon megítéljük és ez alapján a fejlődéséhez szükséges teendőket áttekintsük. A potenciál persze csak akkor válhat konkrét eredménnyé, ha a települések minél aktívabb szerepet vállalnak a számukra megfelelő vállalati kör megszerzésében és megtartásában, komplex „,szolgáltatáscsomagként” értelmezve önmagukat.

Koltai Zoltán

PTE KPVK Vidékfejlesztési Tanszék, Pécs

koltai.zoltan@kpvk.pte.hu

\section{IRODALOM}

Bakos N.-Hidas Zs.-KeZÁN A. 2011: Területi különbségek Magyarországon. A főbb társadalmi és gazdasági folyamatok az ezredforduló után. - Területi Statisztika 51. 4. pp. 335-357.

BARANYAI N.-BARÁTH G. 2009: A várostérségek gazdasági és társadalmi versenyképességi rangsora. - In: SzIRMAI V. (szerk.): A várostérségi versenyképesség társadalmi tényezői. Dialóg Campus, Budapest-Pécs. pp. 191-201.

BARTA Gy. 2000: A külföldi múködő tőke szerepe a magyar ipar duális struktúrájának és regionális differenciálódásának kialakulásában. - In: HoRvÁTH GY.-RECHNITZER J. (szerk.): Magyarország területi szerkezete és folyamatai az ezredfordulón. MTA RKK, Pécs. pp. 265-281.

BeLUSZKY P. 2000: A magyarországi városok versenyképessége. - MTA RKK, Budapest. 86 p.

Beluszky P. 2003: Magyarország településföldrajza. Általános rész. - Dialóg Campus, Budapest-Pécs. 568 p.

CAMAgni, R. 2008: Regional competitiveness. Towards a concept of territorial capital. - In: CAPELlO, R. -CAmagni, R. -Chizzolini, B.-Fratesi, U. (szerk.): Modelling regional scenarios for enlarged Europe. Springer Verlag, Heidelberg. pp. 33-46.

CAmagni, R. 2009: Territorial Capital and Regional Development. - In: CAPEllo, R.-NiJkAmP, P. (szerk.): Handbook of Regional Growth and Development Theories. Edward Elgar, Cheltenham. pp. 118-132.

Csomós Gy. 2013: Magyarország gazdasági központjainak pozícióváltozása 1992 és 2011 között. - Területi Statisztika 53. 6. pp. 529-550.

EGEDY T. 2012: A gazdasági válság hatása a nagyvárosok versenyképességére Magyarországon. - Földrajzi Közlemények 136. 4. pp. 420-438.

EHRLICH É.-RÉVÉSz G.-SzIGETVÁRI T. 2006: Az infrastruktúra fejlettsége Magyarországon. - In: HoRVÁTH GY. (szerk.): Régiók és települések versenyképessége. MTA RKK, Pécs. pp. 196-235.

ENYEDI Gy. 1993: Társadalmi-területi egyenlőtlenségek és területi politika Magyarországon. - In: ENYEDI Gy. (szerk.): Társadalmi-területi egyenlőtlenségek Magyarországon. KJK, Budapest. pp. 9-21.

ENYEDI Gy. 2012: Városi világ. - Akadémia Kiadó, Budapest. 186 p.

FAZEKAS N.-FÁBIÁN A. 2015: A versenyképesség kulturális és humán aspektusai. - Közép-Európai Közlemények 8. 2. pp. 28-39.

FÁBiÁN A.-Tóth B. I. 2013: A kultúra területi mérhetősége és a kistérségek közmúvelődési jellemzői. - Tér és Társadalom 27. 1. pp. 97-113.

HARCSA I. 2015: A területi fejlettség és egyenlőtlenségek lehetséges értelmezései - kritikai értékelés és kutatási eredmények II. - Statisztikai Szemle 93. 6. pp. 521-551. 
JózSA V. 2017: A vállalati beágyazódás. - Comitatus 27. 1. pp. 78-85.

KIss É. 2010: Az ipar és a közlekedés kapcsolatrendszerének elméleti kérdései. - In: Kiss É. (szerk.): Területi szerkezetváltás a magyar iparban 1989 után. Dialóg Campus, Pécs-Budapest. pp. 40-55.

Kiss J. P.-Szalkai G. 2014: A foglalkoztatás területi koncentrációjának változásai Magyarországon a népszámlálások ingázási adatai alapján, 1990-2011. - Területi Statisztika 54. 5. pp. 415-447.

Koltai Z. 2007: A magyarországi városok versenyképességének vállalati megítélése. Tér és Társadalom 21. 2. pp. 23-42.

Koltai Z. 2014: Sikeres és versenyképes városok, Piackutatás a magyar települések körében. - PTE FEEK, Pécs. 211 p.

Konczosné Szombathelyi M. 2014: A regionális és a vállalati kultúra kölcsönhatásának vizsgálata. - Tér és társadalom 28. 1. pp. 84-98.

Krugman, P. 1993: First Nature, Second Nature, and Metropolitan Location. - Journal of Regional Science 33. 2. pp. 129-144.

Krugman, P. 1994: Competitiveness: a Dangerous Obsession. - Foreign Affairs 73. 2. pp. 28 -44.

Krugman, P. 1998: Space: The Final Frontier. - Journal of Economics Perspectives 12. 2. pp. 161-175.

LENGYEL I. 2012: A kelet-közép-európai országok régióinak versenyképessége. - In: RECHNITZER J.-SMAHÓ M. (szerk.): Jármúipar és regionális versenyképesség. Nyugat- és Közép-Dunántúl a kelet-közép-európai térségben. Széchenyi University Press, Győr. pp. 191-229.

Lengyel I.-REChNitZER J. 2000: A városok versenyképességéről. - In: HoRvÁth GY.-RECHNITZER J. (szerk.): Magyarország területi szerkezete és folyamatai az ezredfordulón. MTA RKK, Pécs. pp. 130-152.

Lengyel I.-Rechnitzer J. 2004: Regionális gazdaságtan. Dialóg Campus, Budapest-Pécs. 391 p.

MAKRA L.-SüMEGHY Z. 2010: Magyarországi városok és megyék osztályozása infrastrukturális és környezeti indikátorok alapján. - Földrajzi Közlemények 134. 2. pp. 203-215.

MÁTÉ É. 2017: Perforált régiók? - Izolálódó térségek a Dél-Dunántúlon. - Földrajzi Közlemények 141. 2. pp. 164-178.

Molnár B. 2009: Foglalkoztatottsági egyenlőtlenségek a magyar nagyvárostérségekben. - In: SzIRMAI V. (szerk.): A várostérségi versenyképesség társadalmi tényezői. Dialóg Campus, Budapest-Pécs. pp. 103-118.

NAGY G. 1995: A külföldi tőke szerepe és térbeli terjedése Magyarországon. - Tér és Társadalom 9. 1-2.pp. 55-82.

NÁRAI M. 2005: A megyei jogú városok innovációs potenciálja. - In: GRosz A.-RECHNITZER J. (szerk.): Régiók és nagyvárosok innovációs potenciálja Magyarországon. MTA RKK, Pécs-Győr. pp. 181-220.

Nemes NAGY J. 1996: Centrumok és perifériák a piacgazdasági átmenetben. - Földrajzi közlemények 120.1. pp. 31-48.

PÉNZES J.-MolnáR E.-PÁLóczi G. 2014: Helyi munkaeró-piaci vonzáskörzetek az ezredforduló utáni Magyarországon. - Területi Statisztika 54. 5. pp. 474-490.

PIRISI G.-TRócsÁnYi A.-Hajnal K. 2018: Általános társadalom- és gazdaságföldrajz. PTE, Pécs. 225 p.

Porter, M. E. 1990: The Competitive Advantage of Nations. The Free Press, New York. 855 p.

Porter, M. E. 1996: Competitive Advantage, Agglomeration Economies, and Regional Policy. - International Regional Science Review 19. 1-2.pp. 85-94.

Porter, M. E. 1999: Microeconomics Competitiveness: Findings from the 1999. Executive Survey. - In: The Global Competitiveness Report. World Economic Forum, Davos. pp. 30-53.

Porter, M. E. 2000: Location, Clusters, and Company Strategy. - In: Clark, G. L.-Feldman, M. P.-Gertler, M.S. (szerk.): The Oxford Handbook of Economic Geography. Oxford University Press, Oxford. pp. 253-274.

RECHNITZER J. 1994: Fejezetek a regionális gazdaságtan tanulmányozásához. MTA RKK, Győr-Pécs. 252 p.

Rechnitzer J.-Csizmadia Z.-Grosz A. 2004: A magyar városhálózat tudásalapú megújító képessége az ezredfordulón. - Tér és Társadalom 18.2.pp. 117-156.

Scotт, A. J. et al. 2001: Global City - Regions. - In: ScotT, A. J. (szerk.): Global City - Regions. Trends, Theory, Policy. Oxford University Press, Oxford. pp. 11-32.

SCOTT, A. J.-STORPER, M. 2003: Regions, Globalization, Development. - Regional Studies 37. 6-7. pp. $579-593$.

Storper, M. 2000: Globalization, Localization, and Trade. - In: Clark, G. L.-FeldMAN, M. P.-GertLer, M. S. (szerk.): The Oxford Handbook of Economic Geography. Oxford University Press, Oxford. pp. 146-165.

SzIRMAI V. 2009: A magyar történeti belvárosok társadalmi sajátosságai. - In: SzIRMAI V. (szerk.): A várostérségi versenyképesség társadalmi tényezői. Dialóg Campus, Budapest-Pécs. pp. 43-56.

То́тн G.-NAGY Z. 2013: Eltérő vagy azonos fejlődési pályák? A hazai nagyvárosok és térségek összehasonlító vizsgálata. - Területi Statisztika 53. 6. pp. 593-612.

VARGA A. 2002: Johann von Thünen és az „új gazdaságföldrajz” térgazdaságtana. - In: BARANCSUK J.-OROSZI S.-VARGA A. (szerk.): Tanulmánykötet Zinhóber Ferenc professzor emlékére. PTE KTK, Pécs. pp. 87-98.

Vernon, R.-Wells, L. T. JR. 1991: The Manager in the International Economy. Englewood Cliffs, New Jersey. 480 p. 